\title{
REGIONÁLNÍ VÝVOJ CEN NEMOVITOSTí 1920 - 1944, KOMPARACE K HOSPODÁŘSKÉMU VÝVOJI
}

\section{REGIONAL REAL ESTATE PRICES 1920 - 1944, COMPARISON OF THE ECONOMIC PROGRESS}

\author{
Václav Beran ${ }^{1}$, Petr Kalčev², Zita Prostějovská ${ }^{3}$ \\ ${ }^{1}$ University of South Bohemia, Faculty of Economics, Studentska 13, 37005 Ceske Budejovice, Czech \\ Republic \\ ${ }^{2}$ EnergySim, Cs. armady 785/22, 16000 Prague, Czech Republic, petr.kalcev@energysim.cz \\ ${ }^{3}$ VSEM, Narozni 2600/9A, 15800 Prague, Czech Republic
}

\begin{abstract}
Abstrakt - CZ
Situace na trhu s nemovitostmi se v období mezi první a druhou světovou válkou vyvíjela v českých zemích dynamicky. Článek shrnuje data získaná z dobové inzerce $(1920$ - 1944) a mapuje trh nemovitostí ve vybraných lokalitách do začátku II. světové války. Do tohoto období patří výrazné ekonomické oživení v období po první světové válce i období zatí̌ené hospodářskou krizí. Vytvořené ekonomické prostředí, Ize nazvat prostředím přehřáté ekonomické konjunktury, přinášelo vysoké zisky. Významné postavení v mechanizmu vzniku hospodářské krize má podnikání s nemovitostmi. Následuje dlouhodobé období vleklé ekonomické krize, následované politickou krizí a II. světovou válkou. Představa o rychlém překonání krize se ve třicátých letech dvacátého století nepotvrdila.
\end{abstract}

Klíčová slova - CZ

Nemovitost, meziválečné období, ceny nemovitostí

\section{Abstract - EN}

The market situation in the world between World War I and World War II developed rapidly in the Czech lands. The article summarizes the data acquired by Decorating Ads (1920-1944) and maps the real estate market in selected locations to the beginning of the Second World War This period includes a significant economic recovery in the aftermath of the First World War and the period of economic crisis in the era after the First World War. The created economic environment, which can be called the environment of overheated economic boom, was bringing high profits.

An important position in the mechanisms of the origin of the economic crisis is business with real estate. The long-term period of protracted economic crisis follows, followed by the political crisis, and the Second World War. The notion of rapid overcoming the crisis was not confirmed in the 1930s.

Keywords - EN

Real Estate, Interwar Period, Real Estate Prices

\section{JEL Classification}

R3, N14

DOI: https://doi.org/10.14311/bit.2017.02.06

Editorial information: journal Business \& IT, ISSN 2570-7434, CreativeCommons license (c) () published by CTU in Prague, 2017, http://bit.fsv.cvut.cz/ 


\section{Úvod}

Historická data jsou velmi často využívána k odhadům budoucího vývoje i identifikaci možných rizikových faktorů.

V souvislosti s trhem $\mathrm{s}$ byty a trhem realit vůbec se často mluví o potřebě spolehlivých indikátorů a jejich vazeb na prognózní vývoj investičních aktivit s různým časovým horizontem [10], [11].

Trh s nemovitostmi, bytová a investiční výstavba jsou odvětvími, které jako jedny z prvních indikují známky hospodářského zpomalení, prípadně deprese [8], [9].

$\checkmark$ minulosti, ve dvacátých letech minulého století, to byl trh s byty, který s časovým předstihem vykazoval zpomalení. Indikátory hospodářské stagnace vprvních fázích vývoje v minulém století vycházely ze stavu ekonomiky USA. Přes rozsáhlé diference $v$ teritoriu a struktuře bylo evidentní, že př́činy jsou hlubšího charakteru.

\section{Vývoj úrokové míry v minulém století na území českých zemí}

Úrokové míry střednědobých a dlouhodobých investičních úvěrů jsou pro běžná hodnocení vývoje ekonomické situace uznávaným indikátorem pro rozhodování investorů a stavebníků vůbec. Vývoj na území Česka byl v minulém století dynamický. Byl ovlivněn dvěma světovými válkami a poměrně rozsáhlým obdobím úrokových sazeb určovaných státním víceletým plánem. Na obr. 4 je sestaven graf úrokových sazeb úvěrů tak, jak se je podařilo soustředit z podkladů Čsú a dobových statistik. Úrokové míry úvěrů i jsou vodítkem pro stanovení návratnosti investic. Po doplnění o míru komerčního rizika $r$ spojeného s předpokládanou investicí a případně trendem budoucího vývoje $\alpha$ je získán rámec pro požadovanou dobu splacení investice $T$ jako $\frac{1}{i+r}$. Obrázek 1 uvádí průměrné roční úrokové míry.

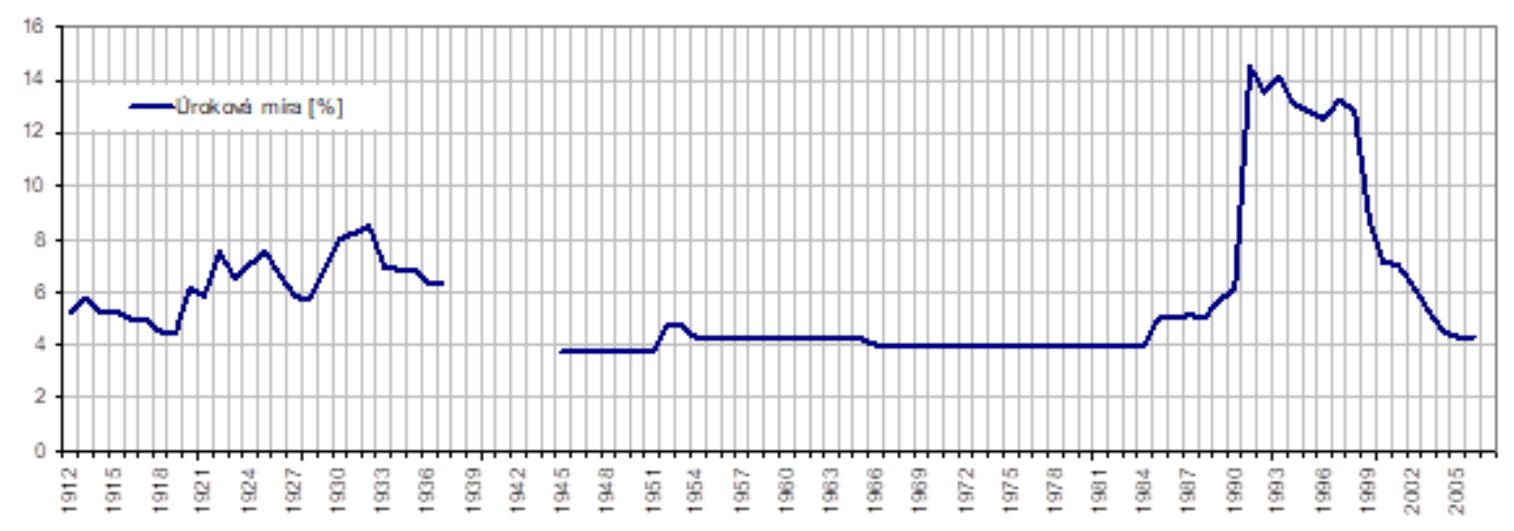

Obrázek 1: Úrokové míry bankovních úvěrů 1912-2006, vlastní zpracování dle [17].

Nastavení diskontních sazeb ČNB od roku 1993 je pro orientaci uvedeno v grafu na Obrázek 2. Obecně se předpokládá, že doba návratnosti investic $T$ se pohybuje v bytové výstavbě mezi 8-18 roky. $\checkmark$ městských aglomeracích rozhoduje bonita lokality, její poloha, perspektivy dalšího užití pozemku a další. 


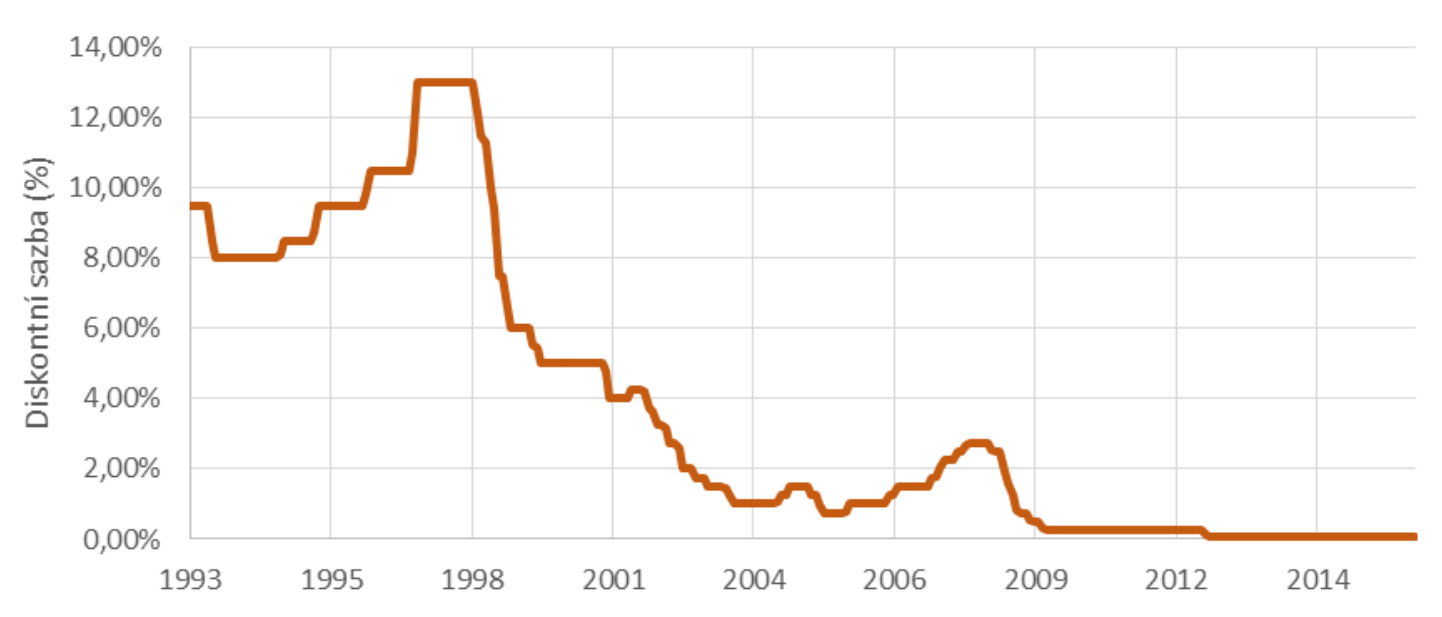

Obrázek 2: Nastavení diskontních sazeb dle ČNB 1993-2013 (úročení depozit komerčních bank u ČNB). [7]

Předpoklad ztíženého investování lze odečíst ze všech vyšších hodnot zobrazených jak v Obrázek 1, tak v Obrázek 2. Dopad na situaci na trhu nemovitostí tehdy a dnes poskytuje raadu paralel. Jedna z nejsilnějších je nesporně dlouhodobost ekonomických vlivů deprese.

Pokud je v následujícím textu použit obrat Česká republika či ČR, rozumí se tím geografická poloha země. Nicméně se celý př́ispěvek věnuje vývoji cen nemovitostí pro Prahu a Středočeský kraj.

\section{Metodika: Inzerce jako zdroj dat a informací}

Data zpracovaná v článku vychází z nabídkových cen nemovitostí určených k bydlení a nájemného na území Středočeského kraje a Prahy v letech 1920-1944. Dohledání dat zpracovatelé řešili fyzickým zjištěním nabídkových inzerátů z regionálních i celostátních deníků prípadně týdeníků [14]. Tiskoviny byly získány v Národní knihovně České republiky v Praze. Celkově bylo sběrem získáno 7668 inzerátů, z toho 6639 pro Prahu. Do průzkumu byly zařazeny tiskoviny Lidové noviny [1], Krakovec [2], Moravskoslezský deník [3], Národní politika [4], Prager Tagblatt [5] a Realito bursa [6]. Do samotného zkoumání nakonec byly vybrány 4 tiskoviny s ohledem na dostupnost inzerce a vlastní dostupnost tiskovin Lidové noviny, Moravsko-slezský deník, Prager Tagblatt a Národní politika. Přehled počtu inzerátů $\mathrm{z}$ jednotlivých titulů je uveden $\mathrm{v}$

\begin{tabular}{|l|c|c|}
\hline \multirow{2}{*}{\multicolumn{1}{|c|}{ Název }} & \multicolumn{2}{|c|}{ Počet vytěžených inzerátů } \\
\cline { 2 - 3 } & Praha & Středočeský kraj \\
\hline Lidové noviny [1] & 7 & 11 \\
Moravsko-slezský deník [3] & 1 & 3 \\
Národní politika [4] & 6194 & 996 \\
Prager Tagblatt [5] & 437 & 19 \\
\hline Celkem & 6639 & 1029 \\
\hline
\end{tabular}

Tabulka 1.

\begin{tabular}{|l|c|c|}
\hline \multirow{2}{*}{\multicolumn{1}{|c|}{ Název }} & \multicolumn{2}{|c|}{ Počet vytěžených inzerátů } \\
\cline { 2 - 3 } & Praha & Středočeský kraj \\
\hline Lidové noviny [1] & 7 & 11 \\
Moravsko-slezský deník [3] & 1 & 3 \\
Národní politika [4] & 6194 & 996 \\
\hline
\end{tabular}




\begin{tabular}{|l|c|c|} 
Prager Tagblatt [5] & 437 & 19 \\
\hline Celkem & 6639 & 1029 \\
\hline
\end{tabular}

Tabulka 1: Použitá periodika a počet vytěžených inzertních záznamů pro Prahu a Středočeský kraj.

Významným periodikem pro sběr informací se stala Národní politika, která poskytuje ve dvacátých a třicátých letech dominantním množstvím inzerátů jak pro Prahu, tak i pro Středočeský kraj.

Při získávání dat ze zmíněných tiskovin se ukázalo, že v častých případech inzeráty ve vydání chybějí. Pravděpodobně proto, že $v$ dané době byly považovány za nedůležité a byly $z$ archivovaných svazků knihoven vypuštěny, případně byly tiskoviny nedostupné $z$ důvodu poškození povodněmi v roce 2002 nebo jsou svazky natolik poškozené, že byly umístěny do archivu a znepř́stupněny.

Vlastní sběr dat probíhal ručně. K zaznamenání informací z inzerátu se využil vlastní software naprogramovaný ve VBA v Excelu. Ten umožňoval nejen zaznamenávat data z inzerátů, ale zároveň vyhodnocoval jejich relevantnost, opakovatelnost a základní statistické údaje. Zhruba $3 \%$ záznamů muselo být vyloučeno právě pro opakovatelnost inzerátů bez jakékoliv změny informace o dané nemovitosti. Celkem bylo sledováno 26 parametrů, mezi který byl např. typ vlastnění objektu, zda jde o prodej či pronájem, podlahová plocha, zda je dostupná elektřina, plyn či voda, aj. Přehled sledovaných parametrů je uveden v Tabulka 2.

\begin{tabular}{|l|l|l|l|}
\hline Cena & Kraj & Počet místností & Ústřední vytápění \\
\hline Část Prahy & Město & Poznámka & Ǔ̌itná plocha \\
\hline Číslo městské části Prahy & Novostavba & Rok postavení & Voda \\
\hline Datum vytištění inzerátu & Okres & Typ inzerátu & Výměra pozemku \\
\hline Elektřina & Plocha nemovitosti & Typ nemovitosti & Zahrada \\
\hline Kanalizace & Plyn & Typ vlastnění & Zdroj inzerátu \\
\hline Katastrální území Prahy & Počet bytů & & \\
\hline
\end{tabular}

Tabulka 2: Parametry sledované v inzerátech - vlastní zpracování

\section{Poznámka:}

Ve dvacátých a třicátých letech v ČSR byly ceny nemovitostí dány nabídkou a poptávkou v daném místě a čase formou volných cen. Prvorepublikové období hospodářské prosperity a stability bylo relativně krátké a vedlo následně k deformaci trhu s nemovitostmi. Od 2. poloviny roku 1937 byl trh s nemovitostmi ovlivňován hrozbou války, politickou a hospodářskou nestabilitou. Po rozpadu ČSR na jaře roku 1939 a po vzniku Protektorátu Čechy a Morava a samostatného Slovenska nabýval trh s nemovitostmi spekulativní charakter. Zejména po integraci hospodářství Protektorátu Čechy a Morava do ekonomiky tzv. Velkoněmecké řiše, dochází k růstu cen nemovitostí. Ekonomickým efektem byla vyšší zaměstnanost, ale současně i ztráta soutěžního prostředí a atributů ekonomiky volného trhu. Stoupla poptávka po nemovitostech umožňujících relativně bezpečné dlouhodobé uložení peněz. Důsledkem bylo všeobecné zvýšení cen obchodovatelných komodit a růst inflace. Protože investice do nemovitostí je obecně považována za bezpečnou investici [15], následovalo hromadné skupování nemovitostí nepřiměřené zvyšování jejich ceny a spekulace s nimi. Protektorátní vláda ve snaze zastavit nepřiměřený růst cen zřídila Nejvyšší úřad cenový s úkolem řídit a kontrolovat cenovou politiku (121/1939 Sb.). Nejvyšší úřad cenový vydal Nařízení o zákazu zvyšování cen ke dni 20. 6. 1939 (tzv. stopceny - č.175/1939 Sb.). Nařízení stanovilo zákaz zvyšování cen nad jejich stav k 20. 6. 1939. Cenová regulace z roku 1939 přerostla po roce 1948 do cenového centralismu a trh $\mathrm{s}$ nemovitostmi téměř přestává existovat. 


\section{Vývoj cen obytných domů regionů Praha a Středočeský kraj v první polovině 20. století}

V letech 1920-1944 se v okrajových částech Prahy (z tehdejší situace) a ve Středočeském kraji bydlelo v obytných domech. Proto se první analýza, která byla provedena, soustředila na vývoj cen domu, který Ize nazývat ze současného hlediska jako rodinný dům. Nicméně v kontextu vybavení, vazby na hospodářskou část tehdejšího obytného domu je třeba přijmout určitý širší, tolerantní pohled na cenu pořízení bydlení, domu obecně, nemovitosti a bytový dům.

Prvotním výsledkem studie je sledovaný vývoj průměrné ceny rodinného domu v Praze a ve Středočeském kraji, který je zachycen na Obrázek 3.

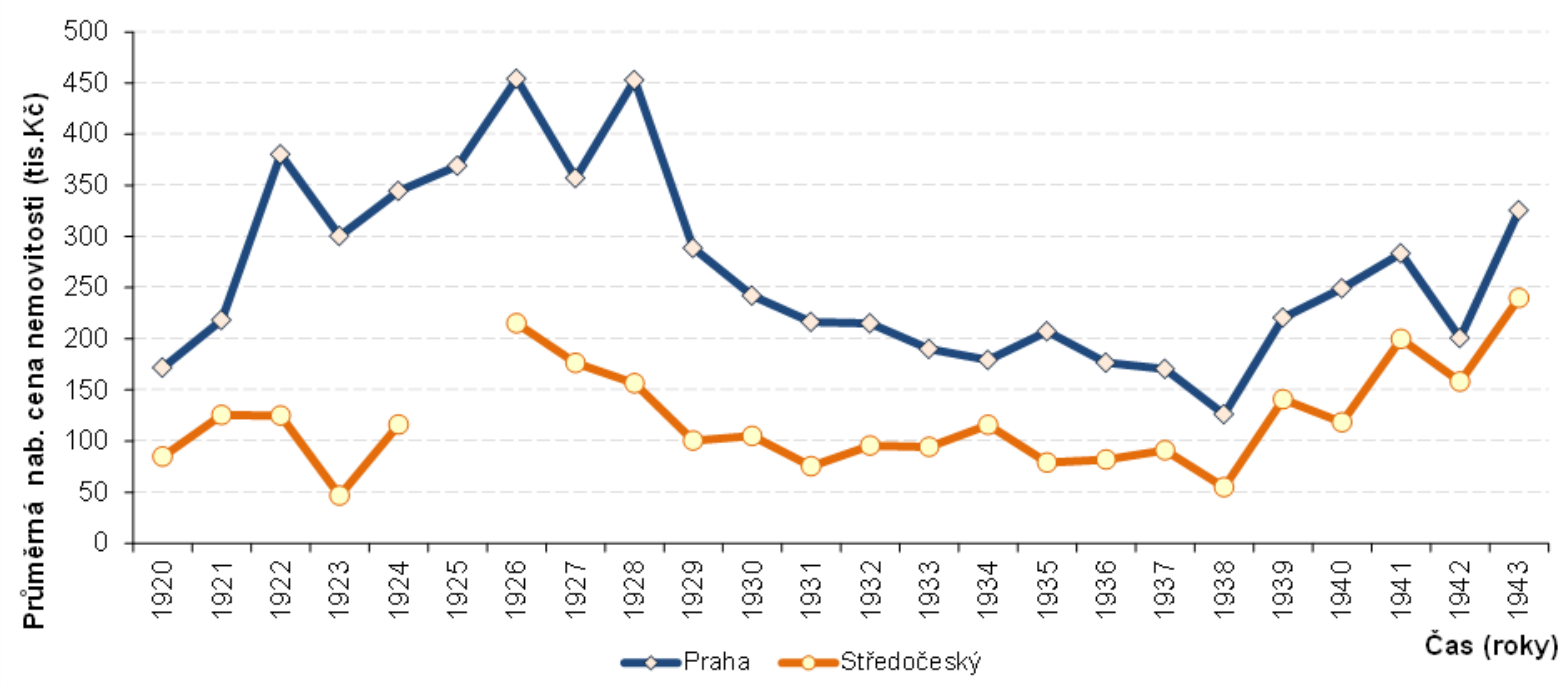

Obrázek 3: Vývoj průměrné nabídkové ceny rodinného domu v Praze (horní) a ve Středočeském kraji (dolni křivka).

Je zde zcela zřejmý vývoj průměrné ceny rodinného domu, která po první světové válce poměrné rychle roste až do roku 1928. V roce 1929 následuje pokles ceny - pro Prahu na 63,7 \% ceny v roce 1928 a pro Středočeský kraj je průměrná cena rodinného domu na $64,2 \%$ ceny rodinného domu oproti předchozímu roku. Tento značný pokles ceny je způsoben začátkem světové hospodářské krize $v$ roce 1929 v USA (datováno k tzv. Black Thursday - 24. ř́jen 1929). Intenzita krize je patrná i po následující léta a měla efekt na vývoj cen nemovitostí po následující dekádu. Krátkodobým důsledkem byl propad cen nemovitostí [11] po rozpadu státu v roce 1938. Obrat v cenách nemovitostí přináší začátek druhé světové války. Dominuje snaha uložit volné finanční prostředky do nemovitostí. Převládá názor, že nemovitosti nebudou znehodnoceny.

Z grafu Obrázek 3 je patrná závislost vývoje průměrné ceny mezi Prahou město a Středními Čechami. Pro uvedenou závislost byla provedena korelační analýza, viz Tabulka 3.

\begin{tabular}{c|c|c}
$\begin{array}{c}\text { Korelační závislost } \\
\text { Praha / Středočeský kraj }\end{array}$ & Praha & Středočeský kraj \\
\hline Praha & 1 & 0,599 \\
\hline Středočeský kraj & 0,599 & 1
\end{tabular}

Tabulka 3: Korelační závislost Praha / Středočeský kraj. 
Z výsledků korelační analýzy plyne cca 0,6 závislost nabídkové ceny v Praze a Středočeském kraji. Tato situace odpovídá i současné situaci, kdy ceny ve Středočeském kraji jsou ovlivňovány nabídkovou hladinou cen v Praze. Důvodem, proč korelační koeficient není hodnota 1 , je dán mírou profitu, zaveden termín zahrnující veškeré benefity své doby. Rozdíl mezi cenou, za kterou je nemovitost prodána a opodstatněnou cenou nemovitosti) na prodeji cen nemovitostí v Praze [11] je v době hospodářské krize významný. Lze bez omezení předpokládat klasické chování prodávajícího, který se v době hospodářského růstu snaží prodat nemovitost s největším možným ziskem.

Vývoj průměrné ceny rodinného domu v Praze za městské části a počet inzerátů uvádí Obrázek 4.

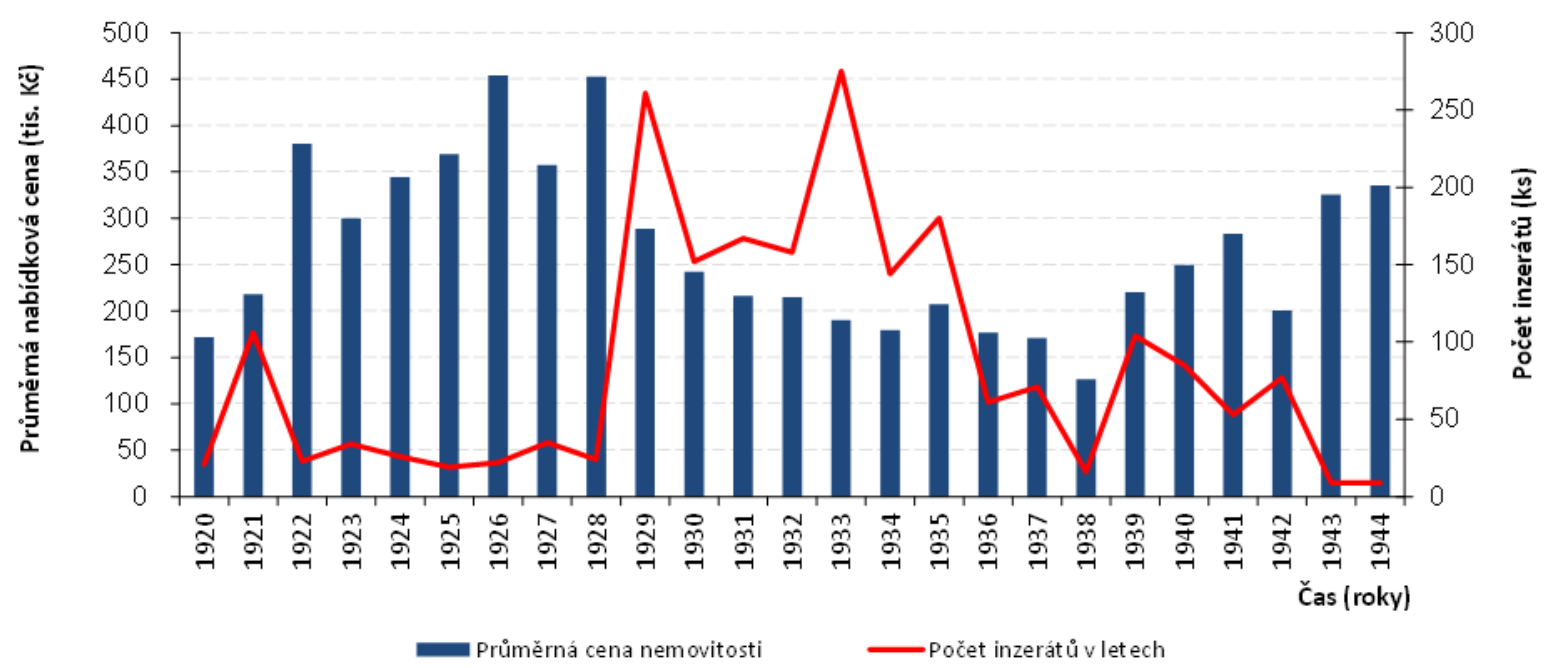

Obrázek 4: Průměrná nabídková cena (histogram) a počet nabídek pro rodinný dům v Praze.

Zajímavý je vývoj počtu inzerentů. V období 1922 až 1928 došlo k poklesu počtu inzerátů a to nejen z důvodu chybějících svazků deníku Národní politika, který je zakonzervovaný v národním archivu. Při sledování vývoje počtu inzerátů od roku 1929 do 1935, Ize konstatovat, že počet inzercí má významný růstový trend.

Vysvětlením je zřejmě snaha majitelů udržet po maximálně dlouhou dobu nemovitost ve vlastnictví za trvalého poklesu cen. Trvání hospodářského poklesu však přesahuje očekávání a prodeje v důsledku finanční tísně zřejmě převažuji i přes klesající trend cen nemovitostí.

Kritické období roku 1929 a 1930 detailně nastiňuje Obrázek 5. Pokud nejsou uvažovány sezónní vlivy, pak v říjnu 1929 je již zřejmá panika nejen na akciovém trhu, ale i v oblasti nemovitostí. Nervozitu završuje pád burzy na Wall Street v říjnu 1929. Je až neuvěřitelné jak silný efekt na nabídkovou cenu má „černý čtvrtek“ na hodnoty nabídkové ceny v následujícím měsíci. Kdy průměrná říjnová nabídka roku 1929 pro ceny rodinného domu v Praze je oproti záŕijové hodnotě o 38 \% nižší. 


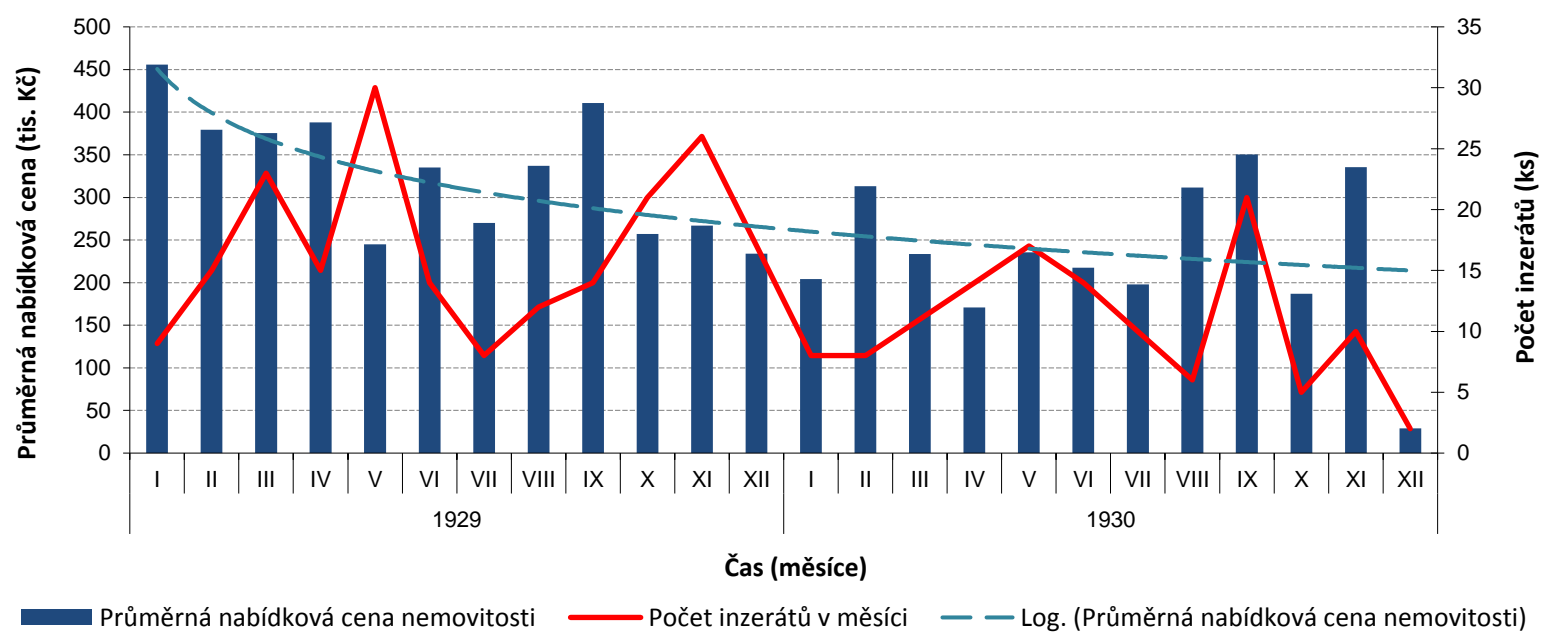

\section{Obrázek 5: Průměrná nabídková cena a počet inzerátů pro rodinný dům v Praze (měsiční} data).

Data je možné prezentovat i v jiné formě a to pomocí ročních diferencí (Tabulka 45). Výsledky indikují, že pokles nabídkových cen za nemovitosti je významný. Výjimku tvoří pouze diference pro listopad, kdy je zaznamenán růst nabídkové ceny. Prosincové hodnoty roku 1930 jsou velmi ovlivněny nízkým počtem inzerátů, který činil jen 2 záznamy.

měsíční cenová úroveň nabídkové ceny roku 1930 oproti roku 1929

\begin{tabular}{|c|c|c|c|}
\hline leden & $44,80 \%$ & červenec & $73,30 \%$ \\
\hline únor & $82,50 \%$ & srpen & $92,50 \%$ \\
\hline březen & $62,30 \%$ & září & $85,30 \%$ \\
\hline duben & $44,00 \%$ & říjen & $72,80 \%$ \\
\hline květen & $96,10 \%$ & listopad & $125,60 \%$ \\
\hline červen & $64,90 \%$ & prosinec & $12,40 \%$ \\
\hline
\end{tabular}

Tabulka 4: Roční diference pro průměrnou nabídkovou cenu rodinného domu v Praze.

Obrázek 6 nastiňuje situaci ve Středočeském kraji. Opět je možné sledovat jak vývoj průměrné ceny rodinného domu, tak počtu inzerátů. 


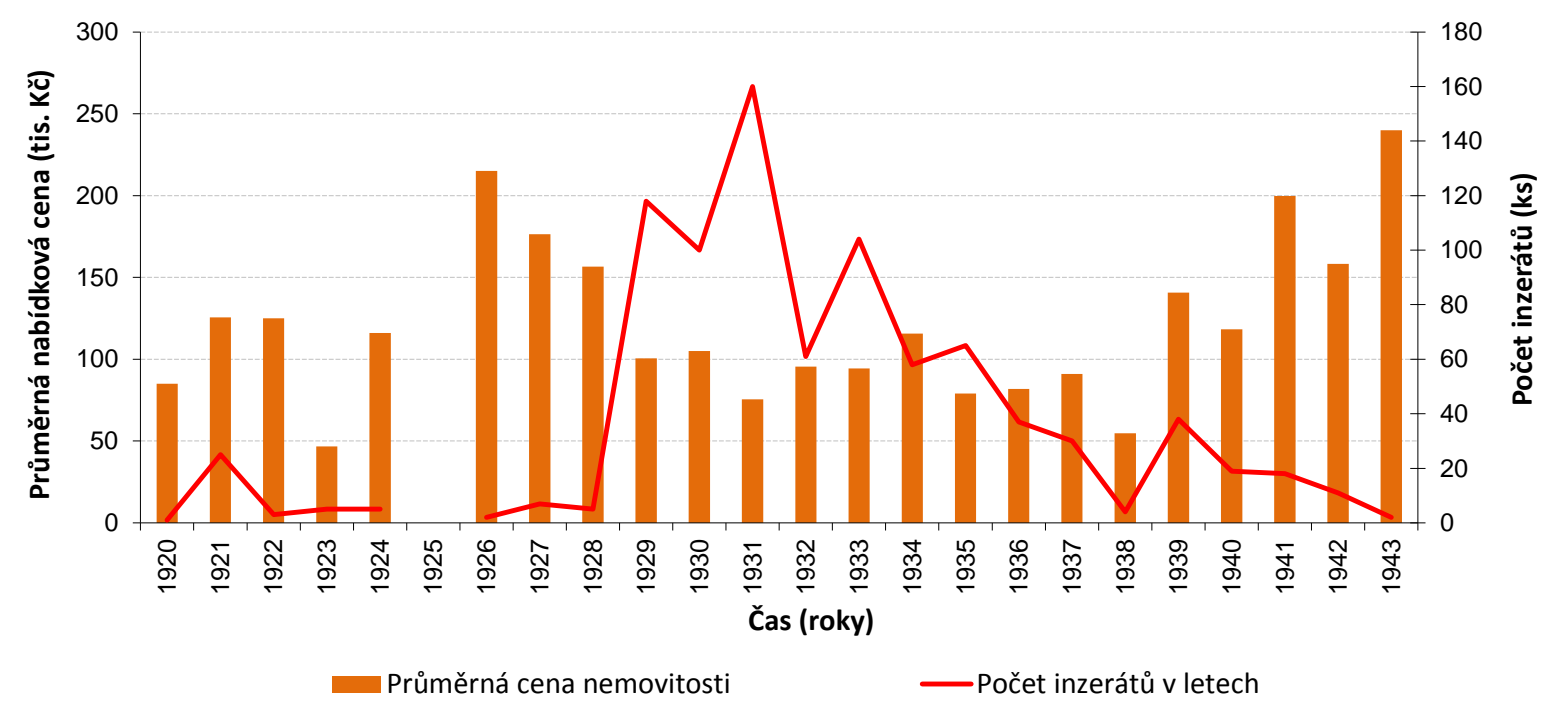

Obrázek 6: Prüměrná nabídková cena a počet nabídek pro rodinný dům ve Středočeském kraji.

Vrat'me se k Obrázek 5, Obrázek 6 a pokusme se pochopit chování dobových aktérů. Připomeňme situace, které se $v$ té době odehrávaly, hospodářská krize a bližící se druhá světová válka. Od roku 1928 již průměrná cena nemovitosti na trhu klesá. $\mathrm{S}$ postupem času se začínají projevovat vlivy ohrožení Německem v Evropě a jeho (nejen) územními nároky. Myšlení lidí se posouvá do negativních rovin a snaží se o co nejlepší likviditu svého majetku. $V$ důsledku toho jsou ochotni snížit svůj profit na prodeji nemovitosti či dokonce jít i pod pořizovací náklady. Trvá-li tento tlak dostatečně dlouho, pak lze říci, že v průměru jsou nabídky podávány ve výší skutečné ceny nemovitosti očištěny o složku zisku nebo spekulativní složky ceny [16].

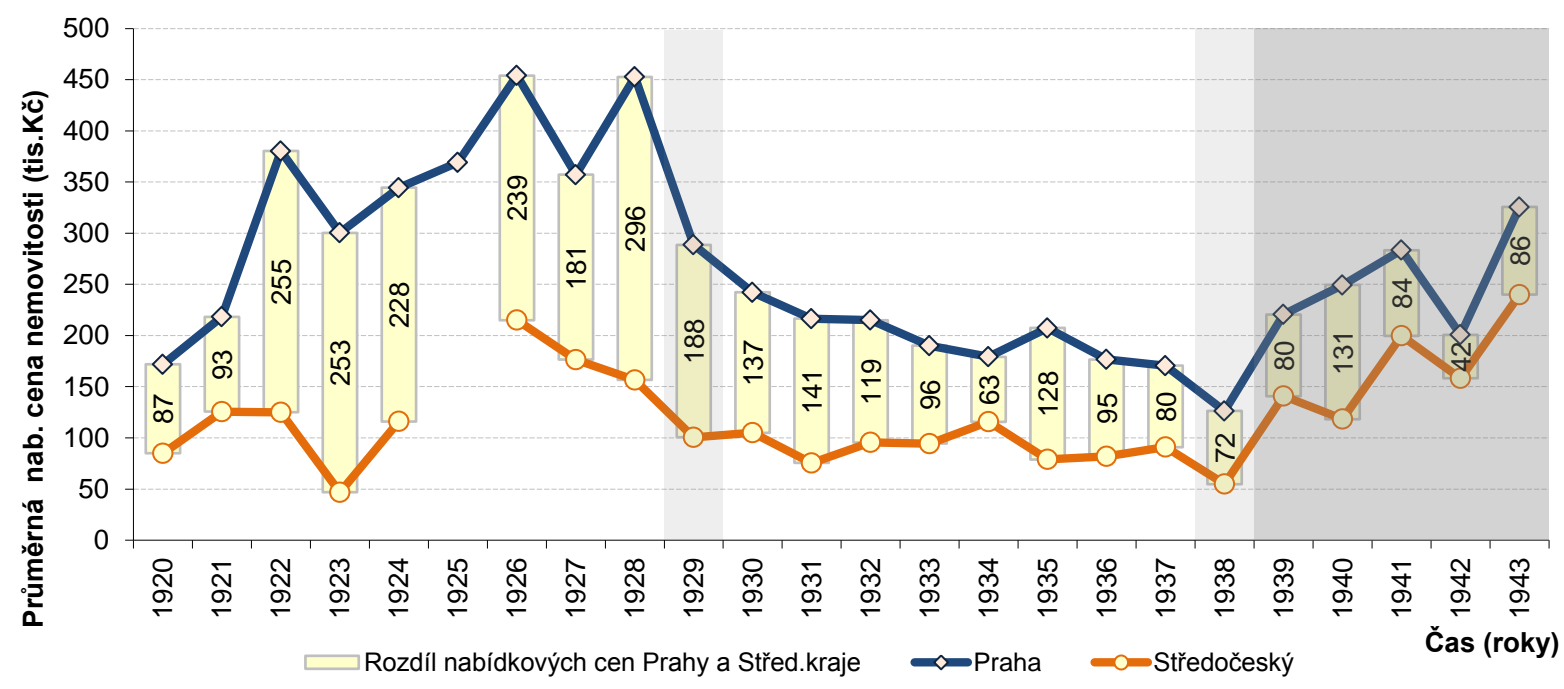

Obrázek 7: Vývoj průměrné nákladové ceny rodinného domu v Praze a ve Středočeském kraji včetnè rozdilu hodnot.

Z dat k uvedenému Obrázek 7 lze usoudit, že mezním prahem mezi hypotetickou cenou kryjící náklady pro Prahu a Středočeský kraj je možné prohlásit nabídkovou cenu bytu/domu v roce 1938. Ta dosahuje 71531 Kč. Uvedenou cenu Ize chápat jako oprávněnou, vyvolanou například dražšími 
pozemky v Praze, lepší dostupností městské hromadné dopravy, lepší infrastrukturou a podobně. Dlouhodobý profil nabídkových cen prodejů rodinných domů v Praze charakterizuje Obrázek 8.

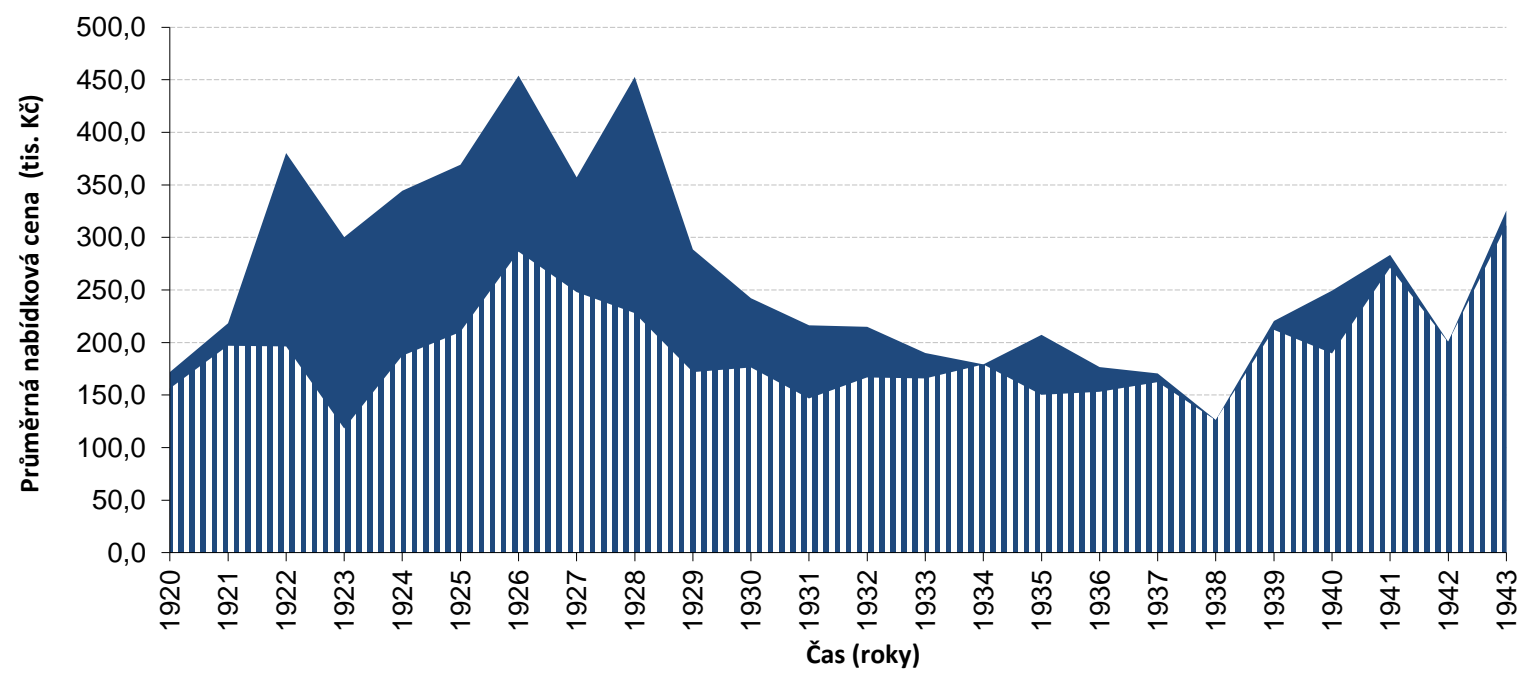

- Profit na nabídkové ceně nemovitosti II Cennová hladina bez profitu

Obrázek 8: Zobrazení průměrného profitu při prodeji rodinného domu v Praze.

Dále bude pozornost soustředěna na jednotlivé části Prahy dle aktuálního rozčlenění. Inzeráty byly rozděleny na segmenty Prahy 1 až Prahy 22 . U některých inzerátů nebylo možné zjistit, do jaké části Prahy patří a tak jsou zařazeny do speciální kategorie: Praha - nezařazeno. Obrázek 9 nastiňuje situaci průměrné ceny rodinného domu dle lokality $v$ Praze.

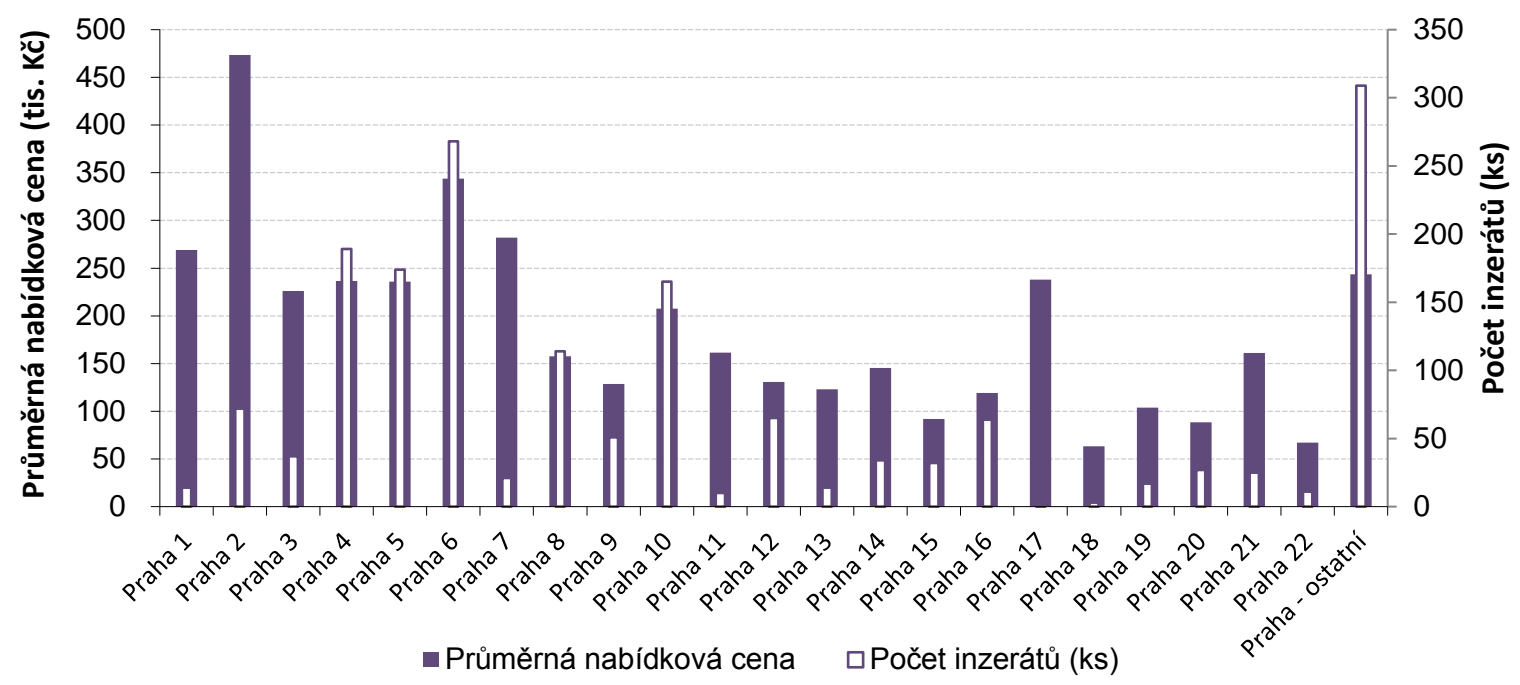

Obrázek 9: Průměrná nabídková cena rodinného domu v období 1920-1944 dle městských částí Prahy.

Průměrná cena rodinného domu v Praze v období 1920-1944 byla 233460 Kč. Mezi tzv. „nejdražši“ lokality v Praze patřila Praha 2, 6 a 7. Je zajímavé, že mezi nejdražší lokality patřila Praha 7, která dříve byla převážně průmyslovou lokalitou. Částečně tuto vysokou nabídkovou cenu lze přiřadit nízkému počtu záznamů a tedy zkreslení průměrné nabídkové ceně, avšak medián je blízký hodnotě průměrné nabídkové ceně. S rozvojem ekonomiky a rozrůstáním Prahy - města, se Praha 7 zařadila mezi 
vyhledávané residenční lokality. Svoji roli zde hrálo napojení dopravní infrastruktury na městské centrum.

Na grafech, Obrázek 10 a Obrázek 11, je zobrazen vývoj cen rodinného domu pro vybrané části Prahy a průměrné ceny $v$ Praze.

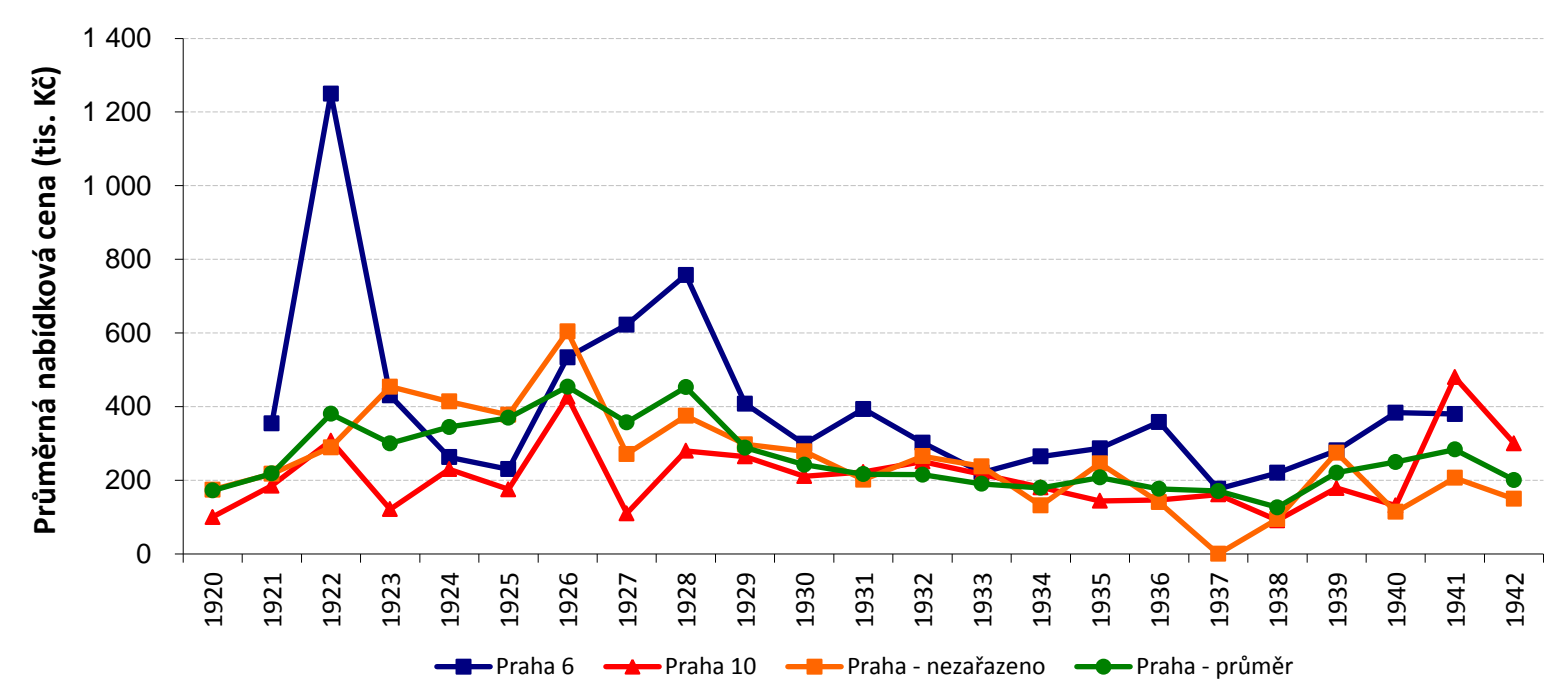

Obrázek 10: Průměrná nabídková cena rodinného domu v Praze 2, 4, 5 a průměr za celou Prahu.

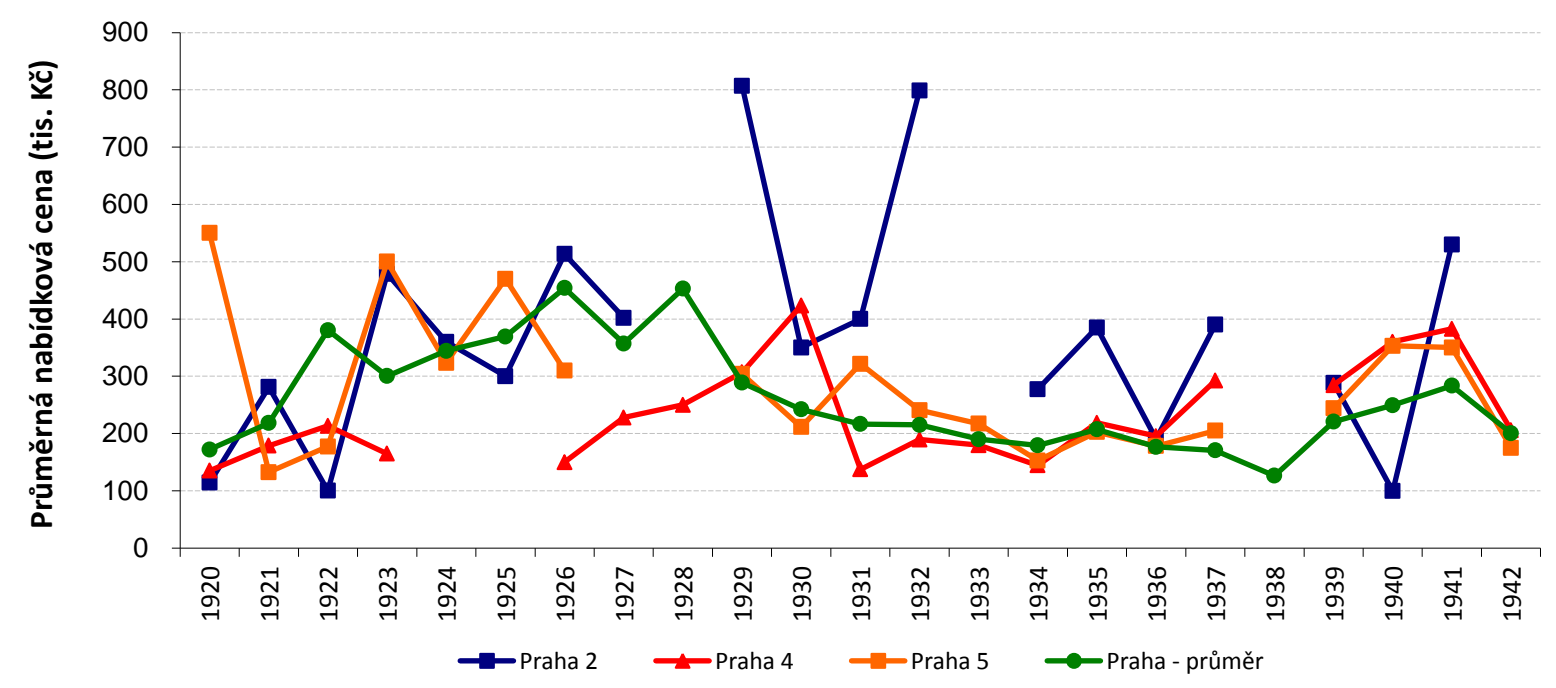

Obrázek 11: Průměrná nabídková cena rodinného domu v Praze 6, 10, nezařazeno a průměr za celou Prahu.

\section{Vývoj cen bytového domu pro region Praha}

Bytový dům je pro Prahu důležitou kategorií pro bydlení. Pro Středočeský kraj ve své době existuje pouze několik inzerátů, proto nebylo území Středočeského kraje podrobeno analýze. 


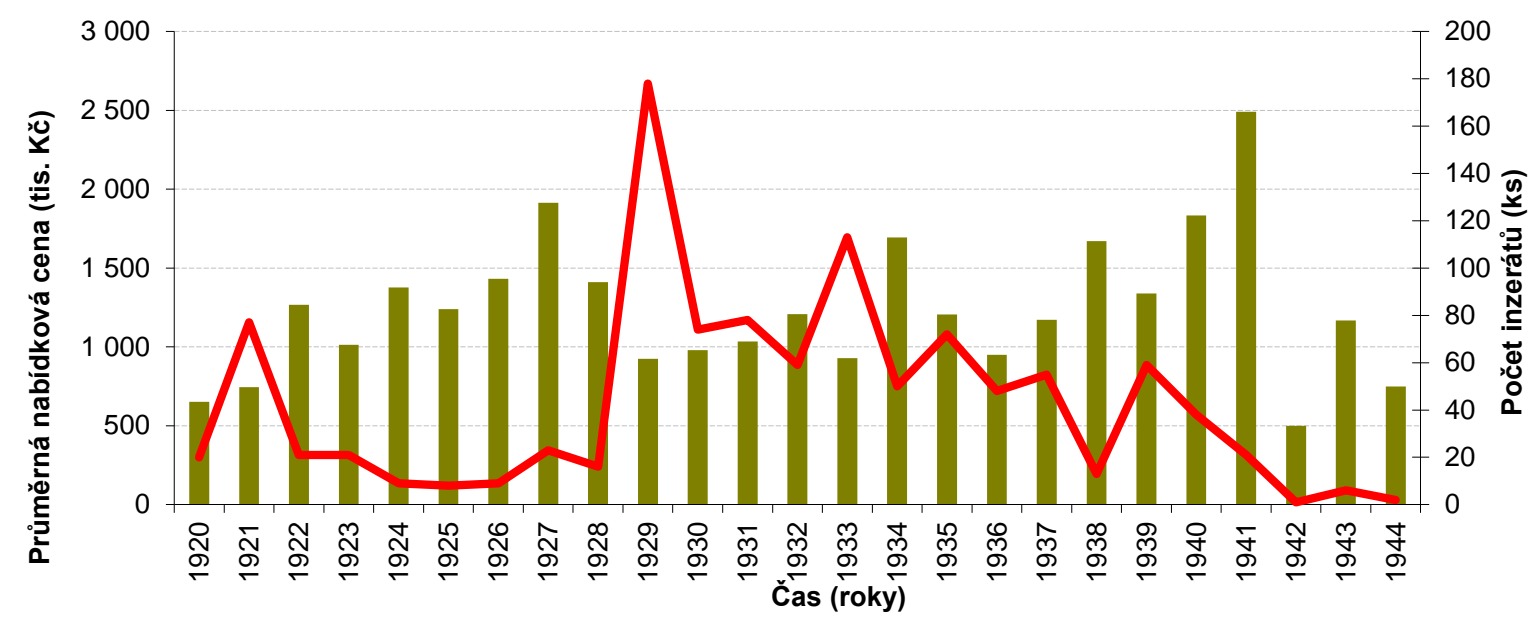

Průměrná nabídková cena Počet inzerátů v letech

Obrázek 12: Průměrná nabídková cena a počet nabídek pro bytový dům v Praze.

Obrázek 12 zobrazuje vývoj průměrné ceny bytového domu v Praze a počet zaznamenaných inzerátů $\checkmark$ jednotlivých letech.

Vývoj ceny má obdobný charakter jako kategorie rodinný dům. Je zajímavé si povšimnout chování vývoje před II. světovou válkou. Ceny nemovitostí začínají růst již od roku 1937. Lze předpokládat, že lidé disponující většími finančními prostředky dokázali odhadnout budoucí vývoj a rozhodli se investovat do nemovitostí dříve, než došlo k znehodnocení měny. Propad cen od roku 1942 a později, je zkreslen nedostatečným množstvím inzerátů a vypočet průměrné nabízené ceny nemovitostí je třeba interpretovat $v$ dobovém kontextu.

Grafy Obrázek 13 a Obrázek 14 zobrazují vývoj průměrných cen ve vybraných lokalitách Prahy. Grafy jsou opět doplněny o časovou řadu reprezentující průměrnou cenu v Praze.

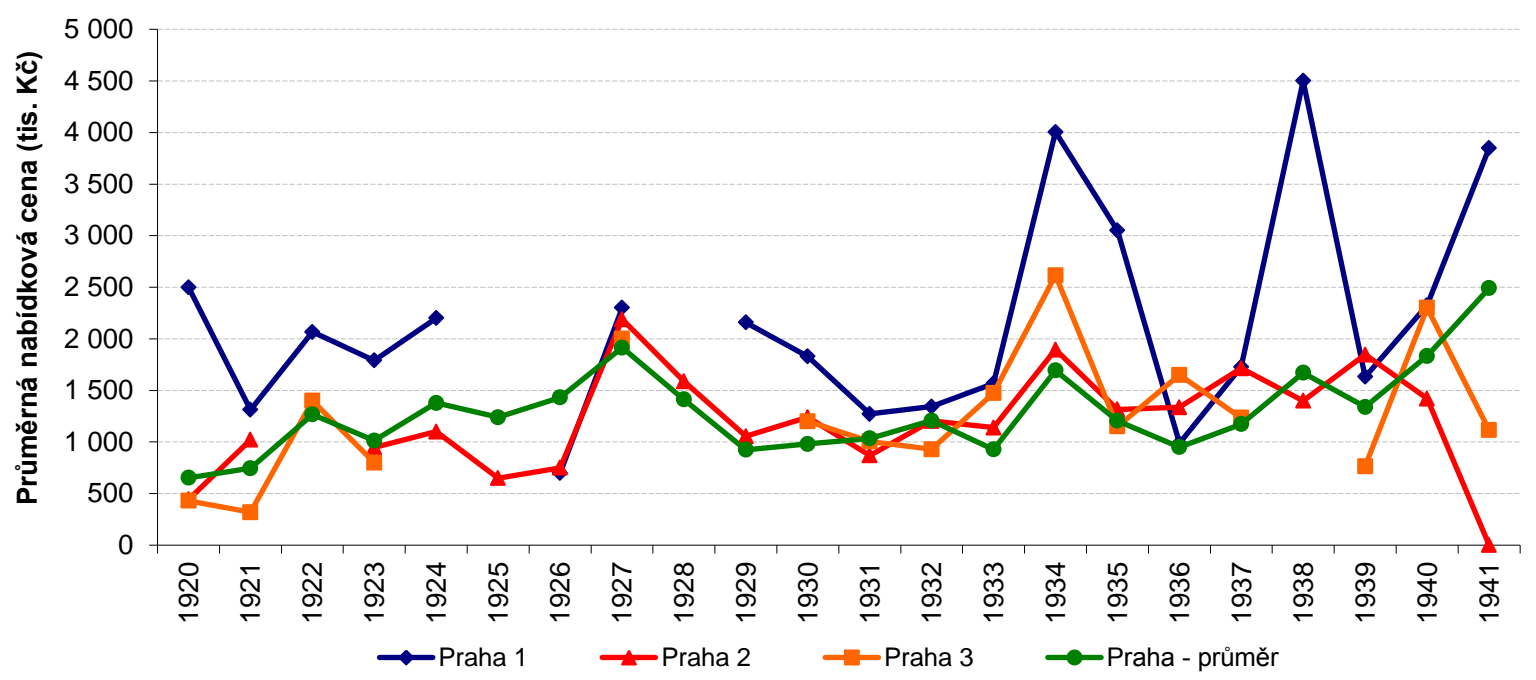

Obrázek 13: Průměrná nabídková cena bytového domu v Praze 1, 2, 3 a průměr za Prahu jako celek. 


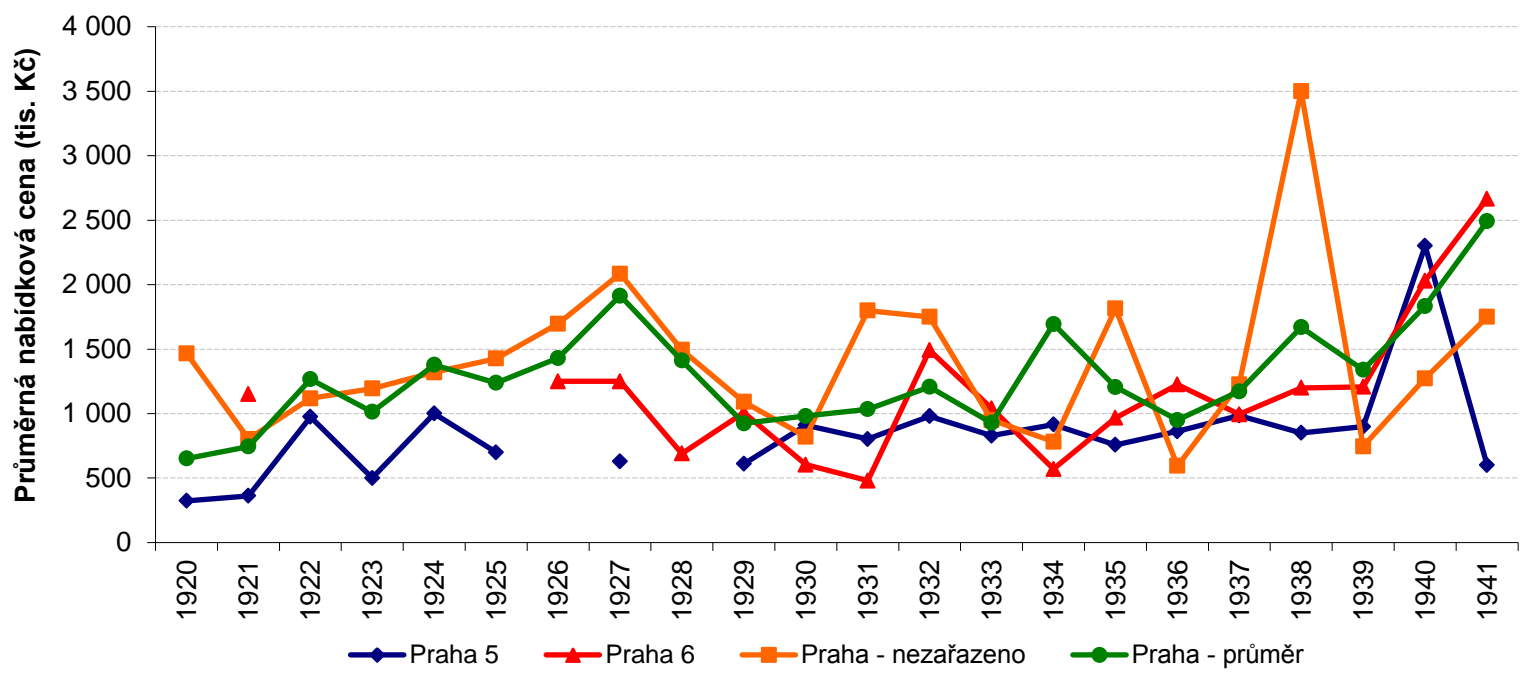

Obrázek 14: Průměrná cena bytového domu v Praze 5, 6, nezařazeno a průměr za Prahu jako celek.

Shluky cen bytového domu s vazbou na rok inzerce zachycuje obr. 18. Graf upozorňuje mimo jiné na zvýšenou aktivitu nabídek (shluk) kolem roku 1933. Roky 1930 a 1933 jsou také zajímavé. Průměrné hodnoty v jednotlivých městských částech se od sebe př́liš neliší. Pro rok 1930 je rozptyl 127 tisíc Kč a pro dok 1933 dokonce pouze 65 tisíc Kč. $\vee$ těchto letech vliv lokality na cenu nemovitosti pozbyl své váhy a rozhodující byl typ nemovitosti, její vybavení apod. Pozornému čtenáři neujde, že v období první světové války se v nabídkách objevují domy v nízké cenové hladině. Krizové období přináší větší disperze v cenách nabízených nemovitostí. S bližící se druhou světovou válkou dochází k prodejům nemovitostí (domů), velkého rozsahu. Jedná se pravděpodobně o prodeje vynucené politickou situací.

\section{Závěr}

Článek vychází z dobové inzerce v krizovém období dvacátých a třicátých let minulého století. Data popisují chování trhu s nemovitostmi po odstartování hospodářské recese a následné hospodářské krize.

Po první světové válce se nesporně vytvořil trh prodávajícího, rostla poptávka a s ní i ceny nemovitostí určených $\mathrm{k}$ bydlení. $\mathrm{K}$ prudkému poklesu nabídkových cen došlo po pádu cen na burze $\mathrm{v}$ roce 1929. Ceny nemovitostí následně dlouhodobě klesaly až do roku 1938. Od počátku II. světové války ceny rostly. Indikátor cena domu vykazuje v segmentu ceny v ČR - Praha vrchol k rokům 1926, 1927, 1929. Uvedené roky vykazují vysoký potenciál ziskových marží (obr. 11). Následný propad bonity bytového domu je dlouhodobý. Od roku 1927 do roku 1929 ceny nemovitostí vykazují nestabilitu a následně pokles, počet nabídek je téměř konstantní. Skokový nárůst nabídek je patrný až v roce 1929. Od roku 1929/1930 nabídkové ceny vesměs degradují. Cenový růst a současný pokles nabídek je patrný od roku 1938. S válečnými událostmi roste cena nemovitostí téměř na úroveň roku 1926, jedná se o maximum před hospodářskou krizí.

Článek si kladl mimo jiné za cíl dokumentovat dosud málo využívaný zdroj informací - dobová inzerce. Pokud by se podařilo motivovat další pracovní skupiny v aglomeracích s dostupným archivem periodik, vzniklo by jistě zajímavé srovnání.

Lze konstatovat, že na základě indikátorů odvozených z trhu s nemovitostmi a zejména z trhu $\mathrm{s}$ rodinnými domy a byty, Ize usuzovat na dlouhodobější dopady rozvoje regionů. Mohou zajímavým 
způsobem doplňovat makroekonomické charakteristiky. Navíc indikují s časovým předstihem situace, které indikují ekonomický zlom. Projekce do současnosti tedy není povrchní.

\section{Seznam literatury}

[1] Lidové noviny: Brno, 1921-1934.

[2] Krakovec: Rakovník, 1904-1906.

[3] Moravsko-slezský deník: Ostrava, 1920-1935.

[4] Národní politika: Praha, 1920-1935.

[5] Prager Tagblatt: Praha, 1922-1928.

[6] Realito-bursa: Brno, 1935-1936.

[7] ČNB, dostuné z www.cnb.cz [cit. cit. 2011-10-08]

[8] ČÁPOVÁ, D.,2003: Doktorská disertační práce. Fakulta stavební, ČVUT v Praze.

[9] FRKOVÁ, J.,2001: Doktorská disertační práce. Fakulta stavební, ČVUT v Praze.

[10] FRKOVÁ, J.,: Analýza vývoje počtu domů v Českých zemích. In Aktuelle fragen der wohnungsentwicklung in CR . Praha: Česká společnost pro rozvoj bydlení, s. 240. 2005. ISBN 80-01-03381-3.

[11] HROMADA, E., PROSTĚJOVSKÁ, Z.; FRKOVÁ, J., BERAN, V., DLASK, P.,: The Software of Reliability Estimation and Risk Evaluation. In Proceedings of Workshop 2007. Prague: CTU, p. 612-613. ISBN 978-8001-03667-9.

[12] JARUŠKOVÁ, D., HÁLA, M.: Pravděpodobnost a matematická statistika, ČVUT Praha, 2002.

[13] KAISER, J., KALČEV, P.,: Ceny nemovitostí a nájemného na území České republiky v letech 1920 až 1935. Proměny bydlení a širší otázky úrovně obslužné sféry. Olomouc 2006

[14] KALČEV, P., 2009: Doktorská disertační práce. Fakulta stavební, ČVUT v Praze.

[15] MACEK, D.: Strategie správy a pořizování nemovitého majetku podniku. In Nová teorie ekonomiky a managementu organizací [CD-ROM]. Praha: VŠE, díl 1, 2008. ISBN 978-80-245-1408-6.

[16] MĚŠŤANOVÁ, D.: Specifika vývojových aspektů bytového trhu. In Ekonomické a riadiace procesy v stavebníctve a v investičných projektoch. Bratislava: Slovenská technická univerzita, s. 74-77. 2007. ISBN 978-80-227-2778-5.

[17] Základní demografické údaje ve vybraném území, citace 1.4.2010. Dostupné na www: $<$ http://vdb.czso.cz/vdbvo/tabparam.jsp?cislotab=DEM9010UC\&kapitola_id=19\&voa=tabulka\&go_zobra $\mathrm{z}=1$ \& childsel0=2> [cit. 2010-04-01] 